\title{
TREATMENT OF DISTILLERY SPENT WASH BY ANAEROBIC DIGESTION PROCESS
}

\author{
Shashikant.R.Mise ${ }^{1}$, Rajani.Saranadgoudar ${ }^{2}$, Rajendra.Lamkhade ${ }^{3}$ \\ ${ }^{I}$ Professor, Department of Civil Engineering, ${ }^{2}$ M.Tech, Scholar, Department of Environmental Engineering, \\ PDA College of Engineering, Gulbarga \\ ${ }^{3}$ Associate Professor, Department of Civil Engineering, Pravara Rural College of Engineering, Ahmednagar \\ srmise45@yahoo.com,rrajani.pda@gmail.com,rklamkhade@yahoo.com
}

\begin{abstract}
In this study, experiments were conducted to investigate the production of biogas from distillery spent wash by using anaerobic digestion process. A laboratory scale digester with working volume of $8.0 \mathrm{~L}$ was used. The experimental protocol was defined to examine the effect of the change in the organic loading rate on the efficiency of the production of biogas. The digester was operated at different organic feeding rates of $0.5,1.0$ and $1.5 \mathrm{~kg} \mathrm{COD} / \mathrm{m}^{3} . d$. The reactor showed stable performance with highest biogas yield of

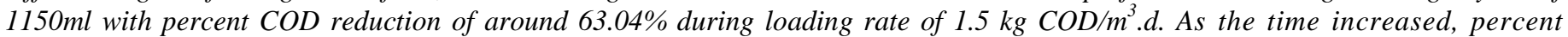
COD removal and gas production increased and attained optimum value for each OLR. The maximum COD removal efficiency and gas produced on $30^{\text {th }}, 60^{\text {th }}$ and $88^{\text {th }}$ day were $79.72 \%, 71.29 \%, 63.04 \%$ and $451 \mathrm{~mL}, 815 \mathrm{~mL}, 1150 \mathrm{~mL}$. Based on data from this study, implementation of anaerobic digestion as the method of waste treatment leads to the regional utilization of renewable energy resources, energy requirements and costs.
\end{abstract}

Keywords: Anaerobic Digestion, BOD, COD, Organic Loading Rate (OLR), distillery spent washes, Reactors.

\section{INTRODUCTION}

There is a growing interest in alternate energy sources as a result of increased demand for energy coupled with a rise in the cost of available fuels. Rapid industrialization has resulted in the generation of a large quantity of effluents with high organic contents, which if treated suitably, can result in a perpetual source of energy. In spite of the fact that there is a negative environmental impact associated with industrialization, the effect can be minimized and energy can be tapped by means of anaerobic digestion of the wastewater. In recent years, considerable attention has been paid towards the development of reactors for anaerobic treatment of wastes leading to the conversion of organic molecules into biogas. The Anaerobic reactors, known as second generation reactors or high rate digesters, can handle wastes at a high organic loading rate of $24 \mathrm{~kg} \mathrm{COD} / \mathrm{m}^{3}$ day and high up-flow velocity of $2 \pm 3 \mathrm{~m} / \mathrm{h}$ at a low hydraulic retention time ${ }^{[1]}$. However, the treatment efficiencies of these reactors are sensitive to parameters like wastewater composition, especially the concentration of various ions [3] and presence of toxic compounds such as phenol ${ }^{[4]}$. The temperature and $\mathrm{pH}$ are also known to affect the performance of the reactor by affecting the degree of acidification of the effluent and the product formation ${ }^{[5]}$. An improvement in the efficiency of anaerobic digestion can be brought about by either suitably modifying the existing digester design or by incorporating appropriate advanced operating techniques. Thus, a anaerobic digester is found to be superior to the conventional processes and stable reactor performance ${ }^{[4]}$. The main objective of this study is to treat the Distillery spent wash using anaerobic process and to characterize the Distillery spent wash for various parameters such as $\mathrm{pH}, \mathrm{BOD}, \mathrm{COD}$, alkalinity, etc. To study the effect of organic loading on the performance of anaerobic digestion process and to find the amount of biogas produced.

\subsection{Anaerobic Digestion (Stages):}

Biogas Production through anaerobic digestion is a biochemical process involving microbial flora of bacteria adapted to oxygen free environment to convert complex biological and organic wastes in sequential stages into Methane, the major energy fuel.

Stage 1: The Hydrolytic Bacteria primarily are involved in the breakdown of complex organic waste streams into simple sugars, fats and oils, and amino acids. This stage involves splitting of the complex organic biological molecules into simpler forms, the process is known as Hydrolysis or Liquefaction.

Stage 2: The Fermentative Acidogenic Bacteria convert the hydrolyzed portion into Organic acids. 
Stage 3: The Fermentative Acetogenic Bacteria then convert the Organic acids into Hydrogen, Acetate and CO2 (g).

Stage 4: Finally, the Methane producing Bacteria, the Methanogens simultaneously produce Biogas from the Acetate, or from Hydrogen and Carbon dioxide.

\subsection{Sources of Wastewater:}

- Process waste streams: Spent wash from the analyser column, Fermented sludge, Spent lees from the rectifier.

- Non-process waste streams: Cooling water, Waste wash water, Water treatment plant wastewater, Boiler blow down, Bottling plant wash wastewater, other wastes.

\section{MATERIALS AND METHODOLOGY}

\subsection{Fabrication and Setting up of Experimental}

\section{Setup:}

The schematic diagram of the experimental setup used for the present study is shown in Figure 1. Aspirator bottle of $10 \mathrm{~L}$ (bottle no.1) capacity was used as digester with working volume of $8 \mathrm{~L}$. The digester was connected to $5 \mathrm{~L}$ capacity bottle (bottle no.2), which contains the brine solution. The liquid displaced by generated gas is collected in the bottle no 3 . The organic loading rate was calculated based upon the working volume of the digester. The organic loading on the digester were $0.5 \mathrm{Kg}$ $\mathrm{COD} / \mathrm{m}^{3} . \mathrm{d}, 1.0 \mathrm{Kg} \mathrm{COD} / \mathrm{m}^{3} . \mathrm{d}, 1.5 \mathrm{Kg} \mathrm{COD} / \mathrm{m}^{3} . \mathrm{d}$

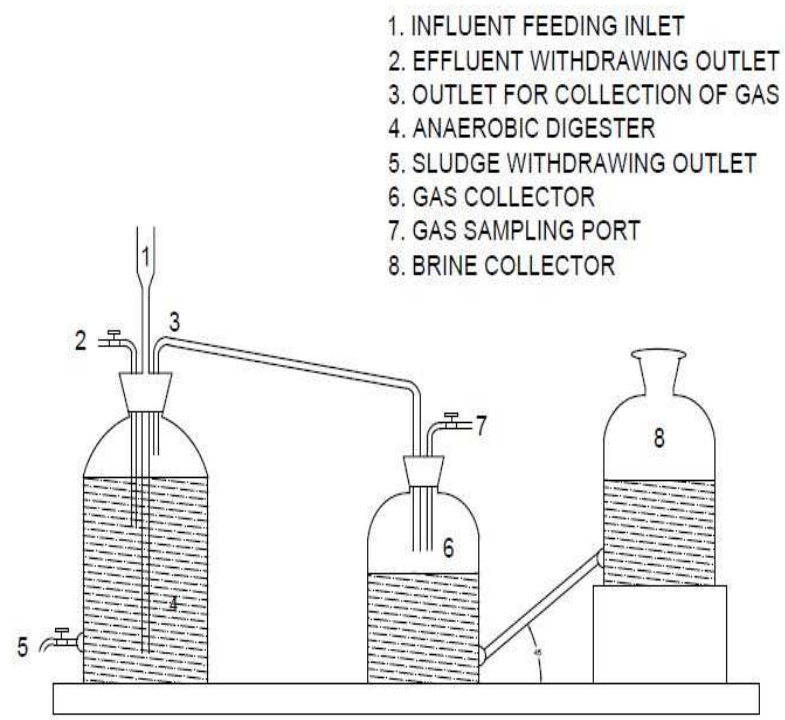

Bottle No.1 Bottle No.2 Bottle No.3

\subsection{Start up of Reactor:}

During the start-up of the reactor, the reactor was loaded with 7.0 L of cow-dung slurry \& $1.0 \mathrm{~L}$ of distillery spent wash with a COD concentration of $40,100 \mathrm{mg} / \mathrm{L}$, this mixture gave a composite COD of $14,800 \mathrm{mg} / \mathrm{L}$. Daily the reactor was loaded with wastewater of volume $100 \mathrm{~mL}$ with a COD concentration of 40,100 mg/L. After 4 days lapse of time the Gas collection started \& by adjusting the reactor $\mathrm{pH}$ every-day the reactor was operated for 30 days for achieving stabilization. During various organic loading, $150 \mathrm{ml}$ of effluent sample was collected for analysis of various physico-chemical parameters such as $\mathrm{pH}, \mathrm{BOD}, \mathrm{COD}$, alkalinity, total solids, etc. and the analysis were carried out as per the standard methods for the examination of water and wastewater (AWWA) $20^{\text {th }}$ edition.

\subsection{General Characteristics of Distillery Spent Wash:}

The fresh wastewater samples were brought from "Padmashree Dr. Vittalrao Viakhe Patil co-operative sugar factory" to P.D.A Engg. College laboratory and preserved in deep freeze, to analyse the typical characteristics. The key pollutants in the spent wash from distilleries are organic compounds and solids. Biodegradability may be estimated on the basis of BOD / COD ratio. This ratio ranges between 0.42-0.64, which indicates that the part of the organic compounds in the waste water is not easily biodegradable. The $\mathrm{BOD}_{5}$ is $30,000 \mathrm{mg} / \mathrm{L}$, COD is $40,100 \mathrm{mg} / \mathrm{L} \&$ Total Solids in wastewater was found to be $8600 \mathrm{mg} / \mathrm{L}$. The $\mathrm{pH}$ value in this case varies from 3.8 4.4. When wastewater contains high concentration of organic matter, dissolved oxygen depletes because of the breakdown of organic matter, in absence of oxygen, sulphate acts as an electron acceptor to produce $\mathrm{H}_{2} \mathrm{~S}$ and odour.

\section{RESULTS AND DISCUSSION}

The results of alkalinity, percentage COD removal and Gas production are shown in Figure 2, Figure 3 \& Figure 4 for varying Organic Loading Rate.

Fig 1: Experimental Setup of anaerobic reactor 


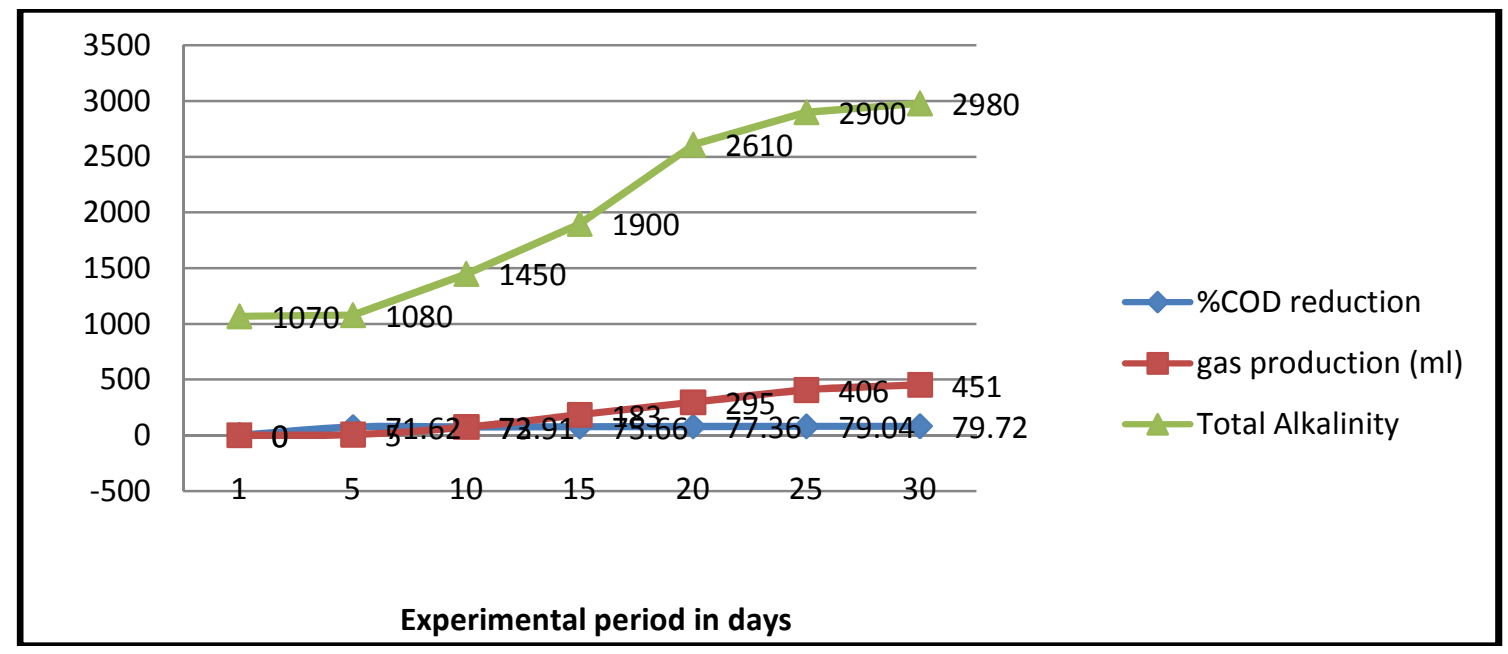

Fig 2: Graph of Total Alkalinity, percent COD removal and Gas production for OLR $=0.5 \mathrm{~kg} \mathrm{COD} / \mathrm{m}^{3} . \mathrm{d}$

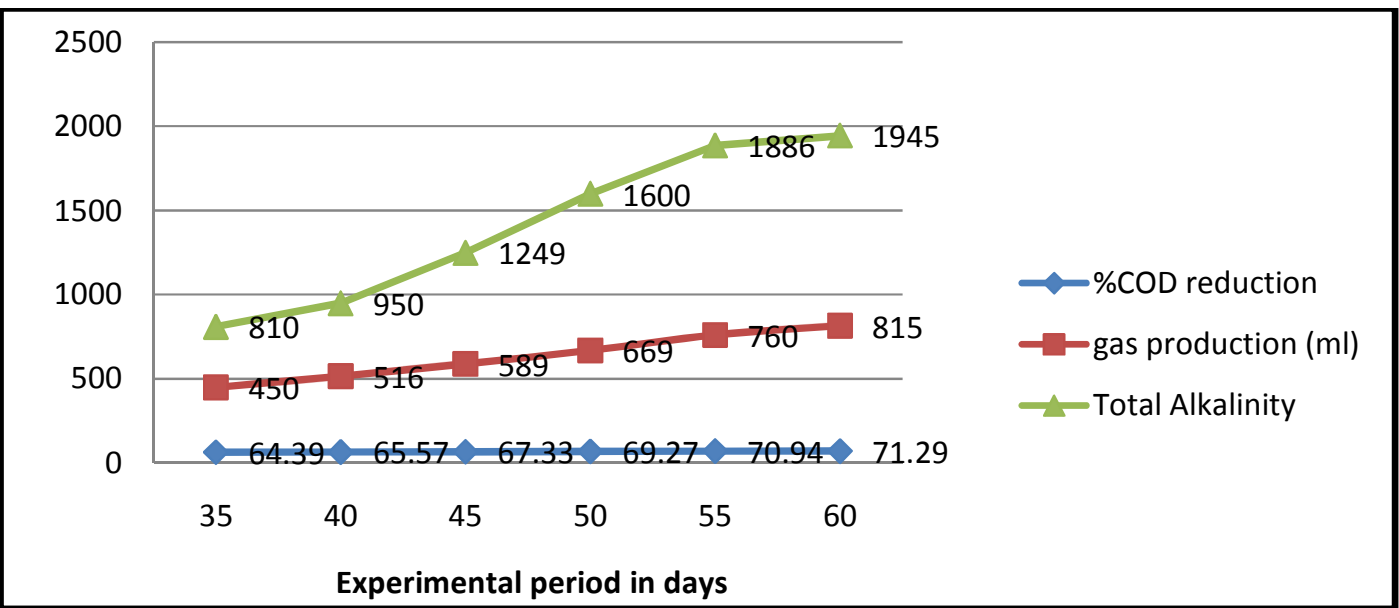

Fig 3: Graph of Total Alkalinity, percent COD removal and Gas production for OLR $=1.0 \mathrm{~kg} \mathrm{COD} / \mathrm{m}^{3} . \mathrm{d}$

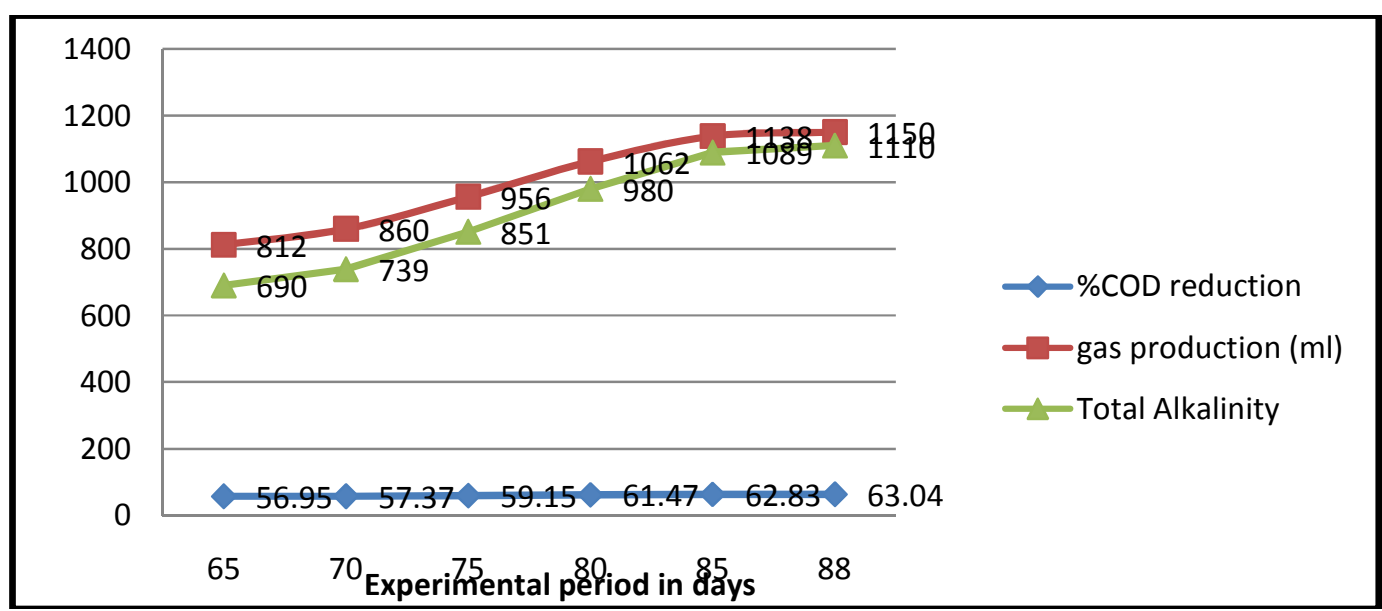

Fig 4: Graph of Total Alkalinity, percent COD removal and Gas production for OLR $=1.5 \mathrm{~kg} \mathrm{COD} / \mathrm{m}^{3} . \mathrm{d}$ 
The reactor was started with an OLR of $0.5 \mathrm{~kg}$ COD $/ \mathrm{m}^{3} . \mathrm{d}$ and operated for a period of 30days till it attains stabilization. During this period the $\mathrm{pH}$ is maintained from 7.02-7.04. The alkalinity increased from 1080-2980 $\mathrm{mg} / \mathrm{L} \&$ and COD reduced from $4200-3000 \mathrm{mg} / \mathrm{L}$, refer Figure 2 . On $30^{\text {th }}$ day the maximum COD removal efficiency obtained is $79.72 \%$ $\&$ gas produced is $451 \mathrm{~mL}$. As the time increased, \%COD removal increased $\&$ attained optimum value on $30^{\text {th }}$ day. When the OLR was increased from 0.5 to $1.0 \mathrm{~kg} \mathrm{COD} / \mathrm{m}^{3} . \mathrm{d}$ $\left(35-60^{\text {th }}\right.$ day) \& operated for a period of 25 days till it attains stabilization. Throughout the study period the $\mathrm{pH}$ is maintained from 7.10-7.03, the alkalinity increased from 810$1945 \mathrm{mg} / \mathrm{L} \&$ COD reduced from 5270-4248 mg/L, refer Figure 3 . On $60^{\text {th }}$ day the maximum COD removal efficiency obtained is $71.29 \%$ \& gas produced is $815 \mathrm{~mL}$. As the time increased, \%COD removal increased \& attained optimum value on $60^{\text {th }}$ day.

When the OLR was increased from 1.0 to $1.5 \mathrm{~kg} \mathrm{COD} / \mathrm{m}^{3} . \mathrm{d}$ $\left(60-88^{\text {th }}\right.$ day) \& operated for a period of 28 days till the reactor stabilises. Throughout the study period the $\mathrm{pH}$ is maintained from 7.02-7.08, the alkalinity increased from $690-1110 \mathrm{mg} / \mathrm{L}$ $\&$ COD reduced from $6370-5470 \mathrm{mg} / \mathrm{L}$ refer Figure 4 . On $88^{\text {th }}$ day the maximum COD removal efficiency obtained is $63.04 \%$ \& gas produced is $1150 \mathrm{~mL}$. As the time increased, \%COD removal increased \& attained optimum value on $88^{\text {th }}$ day.

\section{CONCLUSIONS}

Based on the experimental study it can be concluded that the spent wash is highly organic in nature having high value of COD $(41,100 \mathrm{mg} / \mathrm{L})$. The maximum COD removal efficiency is $79.72 \%$ achieved after $30^{\text {th }}$ day (optimizing time) at an organic loading rate of $0.5 \mathrm{~kg} \mathrm{COD} / \mathrm{m}^{3} . \mathrm{d}$. The maximum biogas produced is $1150 \mathrm{~mL}$ after $88^{\text {th }}$ day of the start of reactor at an OLR of $1.5 \mathrm{~kg} / \mathrm{m}^{3}$.d. It was noticed that the percent COD removal was increased and attained optimum value on $88^{\text {th }}$ day from the start up. As the OLR was increased from 0.5 to $1.5 \mathrm{~kg} \mathrm{COD} / \mathrm{m}^{3}$.d, the volume of gas produced increased form $5-451 \mathrm{~mL}, 451-815 \mathrm{~mL}$ and 812 $1150 \mathrm{~mL}$ respectively, percent COD removal decreased from $71.62-79.72 \%, \quad 64.39-71.29 \%, \quad 56.95-63.04 \%$ and total alkalinity was decreased from $1080-2980 \mathrm{mg} / \mathrm{L}, \quad 810-$ $1945 \mathrm{mg} / \mathrm{L}$ and 690-1110mg/L respectively.

\section{REFERENCES}

[1] Blonskaja, V., Molder, H., Sokk, O., Vaalu, T., 1999. Investi- ". gation of anaerobic treatment of extremely high concentrated waste in the cheese industry. Heleco '99, Environmental Technology for 21st Century, Third International Exhibition and Conference, 3-6 June 1999, Thessaloniki, Greece, pp. 57-62.
[2] Lawrence, A.W. and McCarty, P.L. (1969), "Methane formation in anaerobic treatment", J. Wat. Pollut. Control Fed., Vol. 41, pp. R1-R7.

[3] Dague. R.R. (1968). "Application of digestion theory of digestion control" J. Wat. Pollut. Control Fed., Vol. 40. pp. 2021-2132.

[4] K. Sundar Kumar et al, International Journal of Engineering and Science and Technology, Volume 2(12), 2010, pp. 7785 - 7796.

[5] Gujer, W. and Zehnder. A.J.B. (1983), "Review paper-anaerobic treatment of wastewater in fixed film reactors", Water Science and Technology, Vol. 15 , pp. 1-120. 